\title{
PENGAJIAN REMAJA DAN KONTRIBUSINYA DALAM PEMBENTUKAN AKHLAK GENERASI MUDA DI MUSHOLLAH AL-FATH LEBAK JAYA UTARA 4 RAWASAN SURABAYA
}

\author{
Abdullah \\ STAI Taruna Surabaya
}

\begin{abstract}
Abstrak
Pengajian merupakan suatu kegiatan pendidikan non formal yang dilaksanakan di sebuah tempat ibadah pada suatu masyarakat Islam sebagai wadah untuk mendalami dan mengkaji pengetahuan agama, baik materi akhlak, ibadah, ataupun muamalah. Sedangkan materi yang diajarkan di pengajian remaja di Mushollah Al-Fath ini lebih ke materi akhlak yang bertujuan untuk membentuk akhlak pada generasi muda. Penelitian ini menggunakan pendekatan kualitatif, dengan teknik penelitian observasi, dokumentasi, dan wawancara. Adapun untuk analisa data dalam penelitian ini menggunakan teori Miles dan Huberman (1984), yaitu data reduction, data display, dan conclusion drawing/verification, dan sebagai uji kredibelnya menggunakan triangulasi atau pengecekan data dari berbagai sumber dengan berbagai cara dan waktu. Dan kesimpulan dalam penelitian ini adalah pengajian remaja memiliki kontribusi yang sangat besar dalam pembentukan akhlak generasi muda di kemudian hari, wilayah ini mempersiapkan generasinya dengan hal positif sehingga menjadi sebuah kebiasaan bagi para remaja menghadiri sebuah pengajian, sebagai latihan penanaman rasa tanggungjawab dengan menjadi tutor, tanpa menghilangkan masa remaja mereka, karena masyarakat tetap memberi kebebasan bagi mereka untuk bermain dan bergaul seperti layaknya remaja lainnya.
\end{abstract}

\section{Latar Belakang}

Keyword : Pengajian Remaja, Kontribusi, Pembentukan Akhlak

Generasi muda (remaja) sebagai generasi penerus selanjutnya di masa yang akan datang, maju dan berkembangnya suatu bangsa terletak di tangan mereka, dengan kata lain, jika generasi muda suatu bangsa baik, maka bangsa tersebut akan maju dan berkembang, begitu juga sebaliknya, jika generasi muda suatu bangsa buruk, maka besar kemungkinan pula suatu bangsa akan mengalami kemunduran dan hancur. Generasi muda merupakan generasi penentu yang akan melanjutkan estafet perjuangan bangsa, sehingga penanaman akhlak sebagai langkah awal dalam mempersiapkan kemajuan dan perkembangan bangsa di masa yang akan datang.

Masa remaja (generasi muda) merupakan masa transisi dari anak-anak menuju dewasa, masa ini lebih dikenal dengan masa abu-abu, dimana dalam masa mereka telah dirundung rasa ego yang tinggi, sehingga membutuhkan arahan dan bimbingan. Mereka memiliki rasa keingintahuan yang begitu besar sehingga jika tak tertanam hal positif dalam diri mereka dan kita lengah dalam mengawasi mereka

MODELING: Jurnal Program Studi PGMI

Volume 6, Nomor 2, September 2019; p-ISSN: 2442-3661; e-ISSN: 2477-667X, 231-248 
maka berbagai hal negatif ingin dicobanya. Dalam menelusuri masa remaja, kita harus tetap mengingat bahwa tidak semua remaja sama.

Di zaman sekarang banyak sekali para remaja yang memiliki keberagaman sikap yang memprihatinkan, terutama dalam masalah tingkah laku, sikap, akhlak, dan moral. Seperti berita di media sosial dimana banyak remaja yang terlibat dalam tindakan kriminalitas mulai dari terlibatnya tawuran antar remaja, penggunaan obatobat terlarang, pergaulan bebas, pakaian seksi dan kenakalan-kenakalan lainnya lagi. Seorang remaja tak cukup hanya diberikan siraman rohani berisi sejumlah doktrin agama saja yang kemudian ditelan mentah-mentah, namun doktrin agama ini harus ditelaah lebih dalam sehingga mereka benar-benar telah mengetahui pentingnya pengetahuan agama dan akhlak sebagai bekal pedoman hidup di masa yang akan datang,

Pengetahuan agama sama halnya dengan pendidikan agama Islam, dan akhlak merupakan substansi dari pendidikan agama Islam tersebut. Pendidikan agama dianggap sangat penting, karena dapat membentuk kepribadian yang lebih baik dengan terwujudnya sikap dan tingkah laku dalam sehari-hari. Menurut Zakiah Daradjad :

"Pendidikan agama hendaknya bisa mewarnai kehidupan anak sehingga dengannya benar-benar menjadi bagian dari sebuah kepribadian yang akan menjadi pengendali dalam kehidupan di kemudian hari."1

Islam adalah agama yang bersifat universal, dimana semua kehidupan mulai hal yang kecil sampai hal yang besar diatur dalam sebuah Kitab Suci yaitu Al-Qur'an, kitab yang diturunkan kepada Nabi Muhammad sebagai pedoman hidup agama Islam untuk mencapai tujuan hidup umat Islam. Dalam pandangan Islam, manusia terlahir dalam keadaan fitrah yang suci, Allah SWT menciptakan manusia disertai dengan naluri beragama, yaitu agama tauhid, jika memang kita melihat ada segelintir manusia yang tak beragama, maka mereka hanyalah korban dari pengaruh lingkungan yang tidak ada nuansa agamanya.

Islam mewajibkan bagi para penganutnya untuk mendakwahkan dan mensyiarkan seluruh ajaran yang terkandung di dalamnya, seperti firman Allah dalam surat Ali Imron ayat 104 :

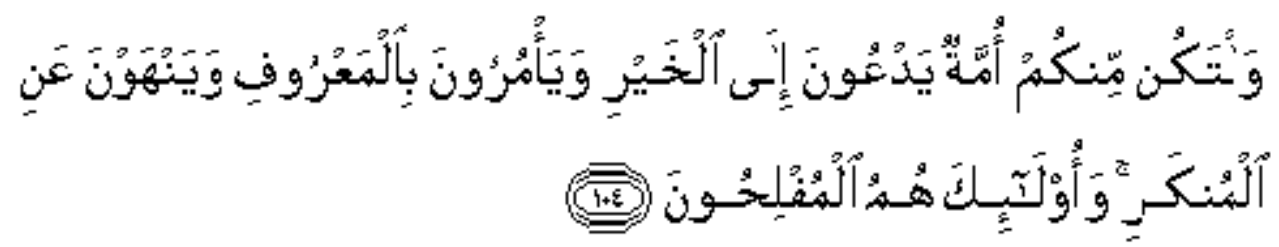

"Dan hendaklah ada diantara kamu segolongan umat yang menyeru kepada kebajikan, menyuruh kepada yang ma'ruf dan mencegah dari yang munkar, merekalah yang beruntung."

\footnotetext{
${ }^{1}$ Zakiah Daradjat, Ilmu Gama, Jakarta : Bulan Bintang, 1970, Cet. Ke-14, 7.
} 
Dalam mensyiarkan Islam yang mengutamakan keimanan dan ketakwaan kepada Allah SWT, maka perlu juga ditanamkan akhlak yang mulia. Karena akhlak tak dapat terbentuk dengan cara yang cepat atau langsung. Jadi, tak mudah juga membentuk suatu akhlak dalam diri seseorang, harus dengan upaya keras dengan melalui proses yang begitu lama dan usaha yang sungguh-sungguh. Dalam pembentukan akhlak generasi muda, harus dengan teladan dan contoh yang baik, dengan pembiasaan secara kontinyu baik melalui pendidikan formal, informal, dan non formal.

Pendidikan agama Islam memiliki beberapa sarana dan prasarana yang dapat kita lihat dalam bentuk dan wujudnya seperti perlengkapan belajar mengajar, tenaga pendidik yang berkompeten dalam bidangnya, tempat proses belajar mengajar yaitu masjid, musholla, sekolah, madrasah ataupun lainnya. Sebagai sarana perkembangan pengetahuan umum diselenggarakan secara formal di beberapa sekolah, sedangkan informal diselenggarakan berada dalam keluarga, dan non formal diselenggarakan oleh masyarakat di beberapa tempat ibadah Islam seperti masjid dan musholla. Tempat ini digunakan sebagai sarana dakwah atau penyebaran agama Islam.

Keberhasilan seseorang dalam mensyiarkan dan mendakwahkan ajaran Islam tergantung pada manhaj (metode) yang digunakan dalam media dakwah. Media dakwah banyak sekali yang dapat diterapkan, seperti tabligh akbar, pidato atau ceramah agama yang khususnya berkaitan dengan sosio kultural masyarakat.

Salah satu pendidikan non formal yang sering terlihat adalah pengajian, dimana kegiatan ini biasa dilakukan di beberapa desa ataupun kota sebagai bentuk perkumpulan majlis dan silaturrahim antar warga dengan pengembangan pengetahuan agama. Prof. Kuntowijoyo mengatakan "Kegiatan ini biasanya berpusat di lingkungan masjid yang mana masjid sangat mungkin sekali melakukan pembinaan terhadap jamaah di wilayahnya."

Sebagai salah satu contoh kegiatan yang diselenggarakan di lingkungan Bulak Setro yaitu pengajian remaja sebagai forum dan wadah persatuan para pemudapemudi setempat, kegiatan keagamaan ini dilaksanakan sebagai kegiatan rutin para remaja setiap malam jum'at, dan mendapat dukungan dari para tokoh masyarakat. Dukungan tersebut tak hanya berupa moril saja, tetapi juga memberikan bantuan materil sebagai kelancaran dalam kegiatan tersebut.

Dalam kegiatan pengajian ini, para remaja diberikan beberapa pendidikan ilmu agama, diharapkan dengan adanya kegiatan tersebut para remaja mampu mengambil dan mengamalkan ajaran agama dengan sebaik-baiknya, serta mengaplikasikan ajaran tersebut dalam bentuk prilaku sehari-hari.

Bagaimana kontribusi pengajian remaja dalam upaya mendidik dan membentuk akhlak generasi muda di lingkungan setempat?. Hal ini masih belum diketahui banyak orang.

2 Depag RI, Al Qur'an dan Terjemahannya, Jakarta: Proyek Pengadaan Kitab Suci Al-Qur'an , 1983/1984, 93. 


\section{KAJIAN TEORI \\ Pengajian Remaja \\ Pengertian Pengajian}

Dalam kamus besar Bahasa Indonesia, pengajian berasal dari kata "kaji" yang berarti pelajaran (terutama dalam hal agama). ${ }^{3}$ Kata pengajian memiliki awalan "pe" dan akhiran "an" yang mengandung dua pengertian : pertama, sebagai kata kerja yang berarti pengajaran, yaitu pengajaran beberapa ilmu agama Islam, dan kedua sebagai kata benda yang menyatakan kata benda dengan arti tempat, yakni tempat melaksanakan pengajaran agama Islam, dimana dalam pemakaiannya digunakan pada banyak istilah, seperti pada masyarakat saat ini yang lebih dikenal dengan majlis ta'lim. ${ }^{4}$ Selanjutnya pengajian mempunyai arti sendiri dalam kamus besar Bahasa Indonesia sebagai : (1) pengajaran (agama Islam), (2) pembacaan Al-Qur'an. ${ }^{5}$

Muzakir mengatakan bahwa pengajian ialah istilah umum yang digunakan untuk menyebut berbagai kegiatan belajar mengajar agama. ${ }^{6}$ Sedangkan Sudjoko Prasodjo menyatakan bahwa pengajian merupakan suatu kegiatan yang bersifat pendidikan kepada umum. ${ }^{7}$

Sementara Hasbullah mengemukakan bahwa pengajian atau majlis ta'lim agama Islam merupakan lembaga pendidikan non formal Islam yang memiliki kurikulum sendiri secara berkala dan teratur yang diikuti oleh jamaah dari seluruh golongan usia. Aktifitas ini tak membatasi umur dan golongan tertentu, tetapi mencakup semua orang yang berminat untuk menjalin silaturrahim dan mendalami ajaran Islam dengan kesadaran masing-masing individu dari mereka. ${ }^{8}$

Pengajian dapat juga dapat dikatakan sebagai syiar Islam yang lebih dikenal dengan sebutan dakwah Islamiyah. Dan dakwah Islamiyah sebagai usaha terwujudnya ajaran agama dalam semua segi kehidupan, sehingga pengajian menyeru kepada yang ma'ruf dan mencegah yang mungkar.

Hidayat Nurwahid mengemukakan bahwa dakwah ialah kegiatan mengajak, mendorong, dan memotivasi orang lain berdasarkan bashiroh untuk meneliti jalan Allah dan Istiqomah di jalan-Nya, serta berjuang bersama meninggikan agama Allah. ${ }^{9}$

Berdasarkan pengertian di atas, dapat disimpulkan bahwa pengajian adalah sebuah kelompok atau jamaah yang memiliki keinginan untuk menambah pengetahuan agama, melalui pendidikan non formal dengan berbagai kegiatan atau

\footnotetext{
3 Tim Redaksi Kamus Besar Bahasa Indonesia, Kamus Besar Bahasa Indonesia Edisi Ketiga, Jakarta : Balai Pustaka, 2005, ed. 3, Cet. 2, 491.

4 Dewan Redaksi Ensiklopedia Islam, Ensiklopedia Islam, Jakarta : Ichtiar Baru Van Hoeve, 1997, Cet. Ke-4, Jilid 3, 120.

5 Tim Redaksi Kamus Besar Bahasa Indonesia, Kamus., 491.

6 Pradjarta Dirdjosanjoto, Memelihara Umat (Kiai Pesantren-Kiai Langgar di Jawa), Yogyakarta : LKIS, 1999, 3.

${ }^{7}$ Bahri Ghazali, Pesantren Berwawasan Lingkungan, Jakarta : Prasasti, 2003, 40.

${ }^{8}$ Hasbullah, Kapita Selekta Pendidikan Islam di Indonesia, Jakarta : Raja Grfindo Persada : 1999, 95-98.

${ }^{9}$ Hidayat Nurwahid, Pengantar Sejarah Dakwah, Jakarta : Kencana, 2012, 2.
} 
aktifitas yang diselenggarakan oleh masyarakat setempat sebagai bentuk pembangunan nilai-nilai agama.

Pengajian pada hakekatmya adalah mengajak manusia pada kebaikan dan petunjuk Allah SWT, menyeru kepada kebiasaan yang baik dan melarang dari kebiasaan buruk agar mendapatkan kebahagiaan dunia dan akhirat. ${ }^{10}$

\section{Tujuan Pengajian}

Ada beberapa tujuan dalam pngajian, diantaranya seperti yang dikemukakan oleh Habib Chirzin tentang tujuan pengajian (ta'lim) ialah

1) Hendaknya sebuah pengajian memberikan petunjuk dan meletakkan dasar ketakwaan dan keimanan dalam semua ketentuan.

2) Dengan adanya pengajian diharapkan mampu memberikan semangat dan meresapi nilai ibadah dalam diri kehidupan manusia.

3) Pengajian sebagai inspirasi, motivasi, dan stimulasi agar jamaah yang memiliki potensi berkembang dan aktif secara optimal. ${ }^{11}$

\section{Remaja}

Asal kata remaja ini adalah adolescence (bahasa latin), yang memiliki arti tumbuh atau tumbuh untuk mencapai kematangan. Adolescence sendiri memiliki arti yang luas, mencakup kematangan mental, emosional, sosial dan fisik. Pandangan tersebut dikuatkan oleh Piaget yang menyatakan secara psikologis bahwa remaja merupakan suatu usia dimana anak tidak merasa jika dirinya tidak berada di bawah tingkat orang yang lebih tua melainkan merasa sama, atau paling tidak sejajar.

Masa remaja merupakan suatu masa yang sangat menarik perhatian para ahli. Banyak ahli yang berpendapat bahwa hakikat masa ini ialah kematangan kehidupan seksual, karena itu tidaklah mengherankan banyak penelitian mengenai anak-anak masa remaja itu dilakukan dalam bidang kehidupan seksual, terutama oleh para dokter.

Menurut E. H. Erikson mengemukakan bahwa adolescence adalah masa dimana terbentuk suatu perasaan yang baru mengenai identitas. Bukti identitas ini mencakup cara hidup pribadi yang dialami sendiri dan sulit dikenal oleh orang lain, sehingga secara hakiki ia tetap sama meskipun telah mengalami berbagai macam perubahan. ${ }^{12}$

Erikson juga menjelaskan masa remaja sebagai masa penangguhan yaitu celah pada waktu dan pada perkembangan pikiran antara keamanan pada masa kanakkanak dengan kemandirian pada masa dewasa. Remaja menggunakan masa penangguhan ini untuk mencari alternatif-alternatif, agar dapat mencapai beberapa resolusi dari krisis identitas, dan muncul dengan pengertian akan dirinya sendiri yang baru dan dapat diterima. Mereka yang mengalami krisis ini akan mengalami kebingungan, rasa tersiksa yang disebut Erikson sebagai identity confusion. Kebingungan ini diekspresikan dalam satu dari dua cara : entah individu tersebut

\footnotetext{
${ }^{10}$ Munzier Suparta, Metode Dakwah, Jakarta : Kencana, 2009, 28.

${ }^{11}$ Habib Chirzin, Pesantren dan Pembaharuan, Jakarta : LP3ES, 1983, Cet. 3, 77.

12 Zulkifli, Psikologi Perkembangan, Bandung : Remaja Rosdakarya, 2002, 63.
} 
menarik diri, mengisolir diri mereka dari teman sebaya dan keluarga, atau ia meleburkan diri dengan kebanyakan orang. ${ }^{13}$

Sementara Dzakiah Drajat berpendapat bahwa masa remaja adalah masa pertumbuhan fisik cepat, dan prosesnya terus berjalan kedepan sampai mencapai titik tertentu. Perubahan sikap yang berlangsung cepat dan tiba-tiba mengakibatkan perubahan lainnya dari segi sosial dan kejiwaan. Sikapnya semakin peka dan berubah-ubah, ego yang tidak stabil, dan kelakuan yang terkadang susah ditebak. Terkadang remaja tersebut menjadi penakut, ragu, cemas, dan sering melontarkan kritikan, terkadang juga memberontak pada keluarga, masyarakat, atau kebiasaan adat istiadat. 14

Dari beberapa pengertian di atas dapat disimpulkan bahwa remaja adalah proses pertumbuhan transisi seseorang dari masa kanak-kanak menuju masa dewasa dengan ditandai beberapa gejala perubahan sikap baik dari segi sosial ataupun kejiwaan. Dan pada masa ini jiwanya mudah terpengaruh dan bergejolak sebagai akibat dari pribadinya yang belum terbentuk, kebingungan pikiran dan emosi berjuang untuk menemukan jati diri, memahami, dan menyeleksi apa yang mereka lihat di lingkungan sekitar, serta kuatnya keinginan bebas tanpa terikat dengan suatu hal apapun.

Jadi, pengajian remaja adalah suatu kegiatan kelompok atau jamaah untuk belajar pengetahuan ilmu agama yang dilakukan dan dilaksanakan oleh seorang yang bermasa transisi sebagai pencarian jati diri, sehingga diharapkan membentuk karakter yang dibekali nilai-nilai agama di kemudian hari.

\section{Pengertian Kontribusi}

Kata kontribusi ini diambil dari bahasa inggris yakni contribute, contribution, yang memiliki arti keikutsertaan, keterlibatan, melibatkan diri ataupun sumbangan. Dari sini kontibusi dapat berupa materi atau tindakan, dimana yang bersifat materi seperti seorang individu yang memberikan pinjaman terhadap pihak lain demi kebaikan bersama, dan kontribusi yang bersifat tindakan berupa prilaku individu yang kemudian memberikan dampak positif dan negatif terhadap pihak lain. Seperti seseorang yang melakukan kerja bakti atau gotong royong di lingkungan rumah guna menciptakan suasana asri sehingga memberikan dampak positif bagi penduduk sekitar, baik penduduk lama ataupun pendatang. ${ }^{15}$

Menurut Soerjono dan Djoenaesih kontribusi adalah keikut sertaan dalam memberikan ide, tenaga, dan lainnya dalam suatu kegiatan. ${ }^{16}$ Sedangkan Gunadi dan Djony mengemukakan bahwa kontribusi merupakan pemberian dalam suatu kegiatan baik berupa informasi, ide, tenaga, untuk mencapai suatu yang direncanakan. ${ }^{17}$

\footnotetext{
${ }^{13}$ Laura A. King, The Science Of Psicology : An Appreciative View, Jakarta : Salemba Humanika, 2012, 192.

14 Zakiah Drajat, Remaja Harapan dan Tantangan, cet. Ke-2, Jakarta : Ruhama, 1995, 14.

15 Anne Ahira, Terminologi Kosa Kata, Jakarta : Aksara, 2012, 77.

16 Soerjono dan Djoenaesih, Istilah Komunikasi, Yogyakarta : Liberty, 1997, 45.

17 Gunadi dan Djony, Istilah Komunikasi, Jakarta : Grafindo Persada, 2013, 76.
} 
Dalam hal ini, kontribusi dapat juga diberikan kepada berbagai bidang, seperti pemikiran, kepemimpinan, profesionalisme, finansial, dan lain sebagainya, sehingga dapat kita simpulkan bahwa kontribusi adalah sumbangsih seseorang dalam berbagai macam kegiatan baik itu berupa materi ataupun tindakan sebagai andil mereka dalam suatu kegiatan yang telah dilaksanakan pada saat itu.

\section{Pembentukan Akhlak dan Generasi Muda Pembentukan Akhlak}

Pembentukan memiliki kata dasar bentuk yang memiliki arti gambaran, berawalan "pe" dan akhiran "an" sehingga mengandung arti lain yakni cara, proses, perbuatan membentuk. ${ }^{18}$ Pembentukan disini sebagai hasil dari sebuah proses seseorang sehingga memiliki identitas diri sebagai insan yang baik atau buruk.

Sedangkan Secara etimologi (bahasa), kata akhlak berasal dari bahasa arab sebuah jamak dari kata khuluqun yang memiliki arti tabi'at, adat kebiasaan, peringai, perwira dan agama. Menurut Hamzah Ya'qub bahwa kata khuluqun mengandung sinonim dari kata kholqun (yang diciptakan. Maka dari itu dalam hal ini ulasan akhlak tidak hanya sebatas pada baik buruknya tabiat, adat istiadat/kebiasaan keseharian saja, melainkan juga membahas berbagai masalah yang menyangkut hubungan antara manusia (sebagai makhluk) dengan Allah SWT Tuhan yang Maha Pencipta (Kholiq), hubungan manusia dengan dirinya sendiri, hubungan manusia dengan sesama manusia lainnya, hubungan manusia dngan makhluk lainnya juga. ${ }^{19}$

Dan secara terminologi (istilah), akhlak dapat dilihat dari beberapa pendapat para ahli. Menurut Ibnu Maskawaih akhlak yaitu suatu dorongan dari sifat seseorang yang tertanam sejak lama dalam jiwa untuk melakukan perbuatan tanpa memerlukan pemikiran dan pertimbangan terlebih dahulu. ${ }^{20}$

Imam Ghozali menjelaskan bahwa akhlak merupakan sifat tetap jiwa, yang mana dari sinilah timbul perbuatan yang mudah dengan tidak memerlukan dan pertimbangan terlebih dahulu. Dengan demikian dapat disimpulkan bahwa akhlak adalah sebuah sifat yang mendorong seseorang untuk melakukan perbuatan secara tidak sadar karena melekatnya suatu kebiasaan dari seseorang, tanpa berfikir dan pertimbangan.

\section{Ruang Lingkup Akhlak}

Dalam Islam akhlak terbagi menjadi dua yaitu akhlak mahmudah yang lebih dikenal dengan akhlak terpuji dan akhlak madzmumah yang lebih dikenal dengan akhlak tercela, akhlak terpuji merupakan suatu akhlak yang wajib kita terapkan pada kehidupan sehari-hari, sedangkan akhlak tercela adalah akhlak yang harus dijauhi. Sementara ruang lingkup dari akhlak Islam juga terbagi menjadi dua yaitu akhlak terhadap Sang pencipta dan akhlak terhadap sesama makhluk.

\footnotetext{
18 Tim Redaksi Kamus Besar Bahasa Indonesia, Kamus., 136.

${ }^{19}$ Imam Suraji, Etika Dalam Perspektif Al-Qur'an Dan Hadits, Jakarta : Pustaka Al-Husna Baru, 2006, 1.

${ }^{20}$ Beni Ahmad Saebani dan Abdul Hamid, Ilmu Akhlak, Bandung : Pustaka Setia, Cet. 2, 2012, 16.
} 
Akhlak terhadap Sang Pencipta merupakan sikap atau perbuatan manusia sebagai hamba-Nya. ${ }^{21}$ Diantaranya beribadah, berdzikir, berdoa, tawakkal, dan tawaddu' kepada Allah. Sedangkan akhlak terhadap sesama makhluk meliputi :

1) Akhlak terhadap makhluk yaitu akhlak terhadap Rasulullah dan orang tua.

2) Akhlak terhadap diri sendiri yaitu memelihara kesucian dan kerapihan diri, berlaku tenang, menambah ilmu pengetahuan, membina pribadi berdisiplin, pemaaf, sederhana, jujur, dan menghindari sikap tercela. 22

3) Akhlak terhadap keluarga dan sanak saudara yaitu berbakti kepada orang tua, saling menghormati dan menghargai antara yang muda ke yang lebih tua, begitupun sebaliknya, dan saling membina rasa kasih sayang dalam kekeluargaan.

4) Akhlak terhadap tetangga adalah saling menghargai dan menghormati, saling memberi, saling membantu, menghindari dan menjauhi perselisihan yang mengakibatkan permusuhan dan pertengkaran.

5) Akhlak terhadap masyarakat adalah bermusyawarah dalam kepentingan bersama, saling tolong-menolong, saling gotong royong, memuliakan tamu, menghormati dan mentaati norma masyarakat, dan lain sebagainya.

Dan untuk akhlak terhadap selain manusia (binatang dan tumbuhan) adalah dengan kesadaran akan kelestarian lingkungan hidup dan memeliharanya, menjaga dan memanfaatkan alam yang sengaja diciptakan Tuhan untuk kepentingan manusia dan makhluk lainnya. ${ }^{23}$

\section{Faktor-faktor yang Mempengaruhi Akhlak Manusia}

Ada 6 faktor yang mempengaruhi akhlak manusia menurut A. Mustofa yaitu :24

1) Insting ialah suatu alat yang dapat menimbulkan perbuatan sebagai penyampaian tujuan dengan berfikir terlebih dahulu ke arah tujuan tersebut.

2) Dasar bawaan sebagai pola perkembangan dan pertumbuhan manusia yang berasal dari turunan.

3) Lingkungan merupakan suatu keadaan dan kondisi di sekitar kehidupan manusia baik dari alam atau pergaulan,

4) Kebiasaan adalah suatu yang terbiasa dilakukan karena diulang-ulang sehingga tanpa manusia sadari bahwa tindakannya hasil dari pengulangan yang mereka lakukan.

5) Kehendak adalah suatu perbuatan yang manusia inginkan sehingga ia melakukan keinginan tersebut.

6) Pendidikan adalah suatu proses kegiatan belajar mengajar dari yang belum tahu menjadi tahu.

\footnotetext{
${ }^{21}$ Abuddin Nata, Akhlak Tasawuf, Jakarta : Rajawali Pers, 2009, 147.

${ }^{22}$ Abdullah Salim, Akhlak Islam Membina Rumah Tangga dan Masyarakat, Jakarta : Seri Remaja, 1986, 69-70.

${ }^{23}$ Mohammad Daud Ali, Pendidikan Agama Islam, Jakarta : Rajawalin Press, 2008, 357-359.

${ }^{24}$ Mustafa, Akhlak Tasawuf, Bandung : Pustaka Setia, Cet. 3, 2005, 82
} 
Sedangkan menurut Arif Bambang Samsul faktor yang mempengaruhi akhlak remaja bersumber dari faktor eksternal dan internal.

1) Faktor Eksternal meliputi lingkungan keluarga sebagai tempat perkembangan seorang anak sejak awal kelahirannya hingga proses pertumbuhan dan perkembangannya, lingkungan institusional sebagai tempat yang berpengaruh dalam akhlak dan moral berupa institusi ini seperti sekolah formal atau non formal yaitu berbagai organisasi dan perkumpulan,25 lingkungan masyarakat sebagai interaksi sosial dengan teman sebaya dan anggota masyarakat lainnya sehingga dalam hal tersebut sangat berpengaruh terhadap perkembangan seorang anak.

2) Faktor Internal meliputi hereditas yakni pewarisan orang tua kepada anaknya dalam bertingkah laku dan bersikap, baik bersikap baik ataupun tercela, tingkat usia yang berarti ketidakstabilan perasaan dan emosi, kepribadian yang berbeda dalam diri seseorang sehingga berpengaruh terhadap perkembangan seorang anak, dan kejiwaan dalam diri tiap seseorang yang memiliki perbedaan dalam kegoncangan jiwa dan perasaan sehingga terkadang mengalami pertentangan dan ketidakserasian dalam sekolah keluarga dan masyarakat.

\section{Generasi Muda}

Generasi Muda berasal dari dua kata yaitu generasi dan muda, dimana generasi sendiri memiliki arti angkatan, tingkatan dan lainnya, sedangkan muda sebuah kelompok, golongan, kaum muda, sebagai penerus generasi yang akan melanjutkan generasi sebelumnya. ${ }^{26}$ Muda disini juga sinonim dari kata remaja, seperti yang sudah dijelaskan pada bagian atas, remaja merupakan masa transisi anak menuju dewasa, yang sering kali memiliki emosi yang tak terkendali, masa ini sebagai penentu keterbentukan dari sifat seseorang, sehingga pada masa ini arahan dan bimbingan masih diperlukan.

Mengenai umur kronologis beberapa anak dapat dikatakan remaja terdapat berbagai pendapat. Aristoteles mengemukakan dalam buku Psikologi pendidikan karya Sumadi Suryabrata (2008), bahwa masa remaja ini termasuk dalam fase ke III yaitu dimulai dari umur 14-21 tahun. ${ }^{27}$ Sementara pendapat Sigmund Freud fase pubertas kira-kira 12 atau 13 sampai kira-kira 20, pada masa ini impuls-impuls menonjol kembali

Sedangkan menurut Dwi Sulistyo Cahyaningsih, remaja adalah individu yang belum mencapai umur 21 tahun dan belum menikah. Sedangkan jika dipandang dari aspek psikologis dan sosialnya, masa remaja adalah suatu fenomena fisik yang berhubungan dengan pubertas. ${ }^{28}$

\footnotetext{
${ }^{25}$ Yusuf, Psikologi Perkembangan Anak dan Remaja, Bandung : Remaja Rosdakarya, Cet. 10, 2010, 140.

26 Tim Redaksi Kamus Besar Bahasa Indonesia, Kamus., 353.

${ }^{27}$ Sumadi Suryabrata, Psikologi Pendidikan, Jakarta : Rajagrafindo Persada, 2008, 186.

${ }_{28}$ Dwi Sulistyo Cahyaningsih, Pertumbuhan Perkembangan Anak dan Remaja, Jakarta : Trans Info Media, 2011, 90.
} 
Ada 2 fase perkembangan kesadaran generasi muda yang telah dijelaskan oleh Syamsu Yusuf :29

1) Awal Masa Remaja (antara umur 13-16 tahun)

Terdapat perubahan pada masa ini, terutama yang terlihat cepat adalah perubahan jasmani sehingga terjadi kegoncangan emosi, kecerdasan, dan kekhawatiran.

2) Akhir Masa Remaja (anatara umur 17-21 tahun)

Pada masa ini sebagai permulaan masa dewasa, emosi yang mulai stabil dan pemikiran yang mulai matang, dalam kehidupan beragama remaja sudah dapat memilah dan memilih ajaran mana yang dapat mereka ambil, dan mana yang tidak perlu diambil. Pada masa ini memungkinkan para remaja untuk tidak terpengaruh oleh orang-orang yang mengaku beragama, namun tidak melaksanakan ajaran agama dan prilakunya.

Ada juga beberapa tahapan masa remaja yang dikemukakan oleh Dwi Sulistyo Cahyaningsih dalam bukunya pertumbuhan perkembangan anak dan remaja :

1) Masa Remaja Awal

Yaitu periode dimana masa anak lewat dan pubertas dimulai. Masa ini dapat dikatakan sebagai masa transisi Stadium Maturitas Seks (SMS) 1 ke SMS 2 sampai sebelum SMS 3, pada anak perempuan biasanya terjadi antara umur 10-13 tahun, sedangkan pada anak laki-laki antara umur 10,5-15 tahun.

Pada masa ini percepatan tumbuh tinggi anak perempuan bertambah tinggi rata-rata $25 \mathrm{~cm}$, sedangkan untuk anak laki-laki bertambah tingginya rata-rata 28 $\mathrm{cm}$.

Untuk berat badan, pada masa ini anak laki-laki telah mencapai 55 persen dari berat dewasa sedangkan anak perempuan 59 persen, kenaikan berat badan masih sama dengan pada akhir masa anak yaitu $2.0 \mathrm{~kg} / \mathrm{tahun}$

2) Masa Remaja Menengah

Yaitu periode dari Stadium Manuritas Seks (SMS) 3 dan 4, dan kronologis umur tercapainya stadium ini sangat bervariasi, bisa berkisar antara umur 11-14 tahun pada anak perempuan dan 12,5-15 tahun pada anak laki-laki. Masa ini adalah masa perubahan dan pertumbuhan yang paling dramastis.

Pada masa ini percepatan tumbuh tinggi anak laki-laki bertambah rata-rata 28 $\mathrm{cm}$, sedangkan untuk anak perempuan tingginya bertambah rata-rata $25 \mathrm{~cm}$ dari tinggi sebelumnya.

Untuk percepatan berat badan pada anak laki-laki terjadi karena terjadi pertambahan empat kali lipat dari sel-sel otot. Jumlah lemaknya secara relatif dalam tubuh berkurang dari 8 menjadi 7 persen, sedangkan pada anak perempuan percepatan berat badan masa pubertas terutama dikarenakan bertambah besarnya ukuran dan jumlah dari sel-sel adiposit, sehingga kandungan lemak tubuh bertambah

${ }^{29}$ Syamsul Yusuf, Psikologi Perkembangan Anak dan Remaja, Bandung : Remaja Rosdakarya, 2004, 204206. 
dari kira-kira 8 persen sebelum pubertas menjadi lebih dari 20 persen pada saat terjadi puncak percepatan kurva berat badan.

3) Masa Remaja Akhir

Yaitu tahap akhir dari perkembangan pubertas yaitu SMS 5, sebelum masa dewasa, dan untuk umurnya sangat bervariasi. Pada anak perempuan antara 13-17 tahun dan pada anak laki-laki antara 14-16 tahun.

Pada masa ini pertumbuhannya sedikit sekali biasanya hanya terbatas pada dagu akibat aposisi dari tulang pada simsifis mandibda, kemudian diikuti dengan pertumbuhan ke depan dari maksila sehingga rahang lebih menonjol ke depan.

Untuk berat badan pada masa ini jumlah sel otot dan kekuatan otot pada anak laki-laki masih terus bertambah setelah pertumbuhan dari bagian-bagian lain berkurang.

Pada masa awal remaja, pemikiran seorang remaja bersifat egosentris yang berarti remaja merasa bahwa orang lain menyadari dan memperhatikan mereka daripada yang sebenarnya, sebagai contoh seorang anak kelas enam-delapan yang merasa bahwa semua orang menyadari akan jerawat kecil di wajahnya, atau remaja perempuan yang mengatakan kepada ibunya "ibu saya tidak paham dengan apa yang saya alami, ia tidak pernah terluka seperti yang saaya rasakan sekarang, mengapa ia memutuskan saya?"

Aspek dari egosentris remaja yang dapat menimbulkan kerusakan paling besar adalah rasa kekebalan. Keyakinan ini akan mendorong prilaku seperti kebut-kebutan, penggunaan obat-obat terlarang, percobaan bunuh diri, dan prilaku seks yang tidak aman sehingga terkena penyakit menular seksual atau kehamilan remaja.

Sebuah penelitian yang dikemukakan oleh Aalsma, Lapsley, dan Flannery tahun 2006, yang dikutip dalam buku psikologi umum sebuah pandangan apresiatif karya Laura A. King dan diterjemahkan oleh Brian Marwensdy atas siswa kelas enam sampai kelas dua belas menunjukkan bahwa rasa kekebalan berhubungan dengan keterlibatan dalam prilaku berisiko seperti merokok, minum minuman keras, dan kenakalan. Salah satu catatan positifnya adalah rasa kekebalan remaja juga mendorongnya untuk bertindak berani dalam menolong orang lain pada kondisi berbahaya, seperti Jabbar Gibson ketika mengendarai bus sekolah untuk menolong orang-orang di New Orleans yang terkena badai Katrina. ${ }^{30}$

Berbagai faktor juga mempengaruhi keterbentukan jiwa pada masa ini, seperti faktor internal yaitu dirinya sendiri, sebagai pola dasar bawaan manusia sejak kelahirannya dan keluarga sebagai lingkungan awal saat manusia terlahir dengan berbagai pengenalan awal dari manusia seperti bahasa, budaya dan lainnya, maupun faktor eksternal yakni lingkungan sebagai tempat bergaul di sekitar dengan keberagaman sifat dan watak sesorang.

\footnotetext{
${ }^{30}$ Laura A. King, The Science., 2012, 191.
}

241 | MODELING, Volume 6, Nomor 2, September 2019 
Selama masa remaja, individu menghabiskan lebih banyak waktu bersama teman sebayanya dibandingkan dengan ketika mereka masih anak-anak. Pengaruh dari teman sebaya ini dapat berupa hal positif maupun negatif.

Salah satu aspek kunci dalam memiliki hubungan teman sebaya yang positif adalah dengan memiliki satu atau lebih sahabat karib, yang mana remaja dapat belajar menjadi rekan yang terampil dan peka dalam hubungan yang intim dengan menjalin persahabatan yang karib bersama beberapa orang sahabat tertentu. Tentunya, beberapa teman sebaya dan sahabat dapat memberikan pengaruh negatif juga pada perkembangan remaja, penemuan Nation dan Heflinger, Conell dan Dishion tahun 2006, serta Laird tahun 2005 yang dikutip oleh Laura A. King bisa dijadikan pertimbangan yang kemungkinan ada dalam diri seorang remaja dalam bergaul : ${ }^{31}$

a. Bergaul dengan teman sebaya yang antisosial ketika remaja merupakan peramal kuat dalam penyalahgunaan zat, daripada dengan melihat pada hubungannya dengan orang tua.

b. Tingkat keterlibatan teman sebaya yang lebih tinggi terjadi pada awal masa remaja (13-16 tahun) berhubungan dengan tingginya tingkat perilaku kenakalan pada akhir masa remaja (17-18 tahun)

c. Afiliasi teman sebaya yang penentang dihubungkan dengan gejala depresi pada remaja.

\section{Proses pembentukan Akhlak pada Generasi Muda}

Proses pembentukan di sini dapat dilakukan dengan berbagai cara, seperti dengan cara melalui pendidikan, pergaulan, keteladanan, motivasi dan intimidasi, persuasi, dan beberapa latihan.

Untuk cara melalui pendidikan, Ramayulis membagi dalam tiga macam yaitu Pranatal Education (Pendidikan sebelum lahir) yaitu pendidikan saat berada dalam kandungan ibu, dimana prilaku orang tua sangat berpengaruh sekali dalam memberikan rangsangan anak dalam kandungan, Education by Another (Pendidikan oleh orang lain) yaitu pendidikan yang didapatkan dari orang lain seperti teman, guru, kerabat, atau yang lainnya, dan Self Education (Pendidikan Sendiri) yaitu pendidikan yang dilakukan atas dorongan diri sendiri sehingga manusia mampu mendapatkan pengetahuan, seperti membaca buku pengetahuan baik agama atau umum. $^{32}$

Di era zaman seperti saat ini, pembinaan akhlak sangat diperlukan guna untuk menanamkan akhlak atau budi pekerti yang baik dalam diri seorang remaja sehingga dapat membentuk akhlak yang terpuji. Banyak para cendekiawan bahwa kerusakan dan kejahatan yang terjadi sekarang ini akibat dari manusia itu sendiri yang tak lagi memegang dan mengamalkan akhlak terpuji.

\footnotetext{
${ }^{31}$ Laura A. King, The Science., 2012, 195.

${ }^{32}$ Ramayulis, Ilmu Pendidikan Islam, Jakarta : Kalam Mulia, Cet. 1, 1994, 195-199.
} 
Ahmad Amin menegmukakan ada beberapa hal yang harus diperhatikan agar masa muda terlindungi dan terjaga dari kerusakan akhlak :33

a. Berfikir lebih luas

b. Berteman dengan orang-orang yang baik

c. Membaca dan menelisik perjalanan pahlawan yang berfikiran luas

\section{METODE PENELITIAN}

Penelitian ini terfokus untuk memperoleh gambaran tentang pengajian remaja dan kontribusinya dalam pembentukan akhlak generasi muda di Bulak Setro Surabaya. Adapun jenis pendekatan yang digunakan adalah pendekatan kualitatif, karena data yang diambil adalah kualitatif.

Rancangan dalam penelitian ini ialah studi kasus observasi, yang mana menurut Bogdan dan Bigien (1982) merupakan penelitian secara rinci terhadap satu latar, satu subjek, dan satu tempat penyimpanan dokumen atau satu peristiwa tertentu.

Penelitian ini lebih mengutamakan temuan observasi terhadap berbagai fenomena yang ada, wawancara yang dilakukan oleh peneliti sebagai key instrument (instrument penelitian) terhadap latar penelitian secara alami dan langsung. Di sini alasan penting kehadiran peneliti sangat diharuskan. Teknik yang digunakan dalam penelitian ini adalah observasi, dokumentasi, dan wawancara.

Sebagai analisis data peneliti menggunakan teori Miles dan Huberman (1984), yaitu data reduction yaitu perolehan keseluruhan data dari lapangan yang jumlahnya cukup banyak dan dipilih yang penting, data display yaitu pengategorian data lapangan dengan bentuk berupa teks naratif, atau berupa grafik, matrik, network (jaringan kerja), dan chart, langkah terakhir adalah conclusion drawing/verification yaitu penarikan kesimpulan dan verifikasi. ${ }^{34}$ Dan sebagai uji kredibel menggunakan triangulasi atau pengecekan data dari berbagai sumber dengan berbagai cara dan waktu. Peneliti sangat memanfaatkan waktu untuk menggali data, baik dengan observasi, wawancara, dokumentasi, dan lain sebagainya untuk memperoleh data, di mulai tanggal 4 Sepetember 2017 di Bulak Setro Surabaya.

\section{HASIL DAN PEMBAHASAN \\ Sejarah dan Tujuan Pengajian}

Muhollah Al-Fath merupakan sebuah tempat peribadatan di daerah Surabaya Utara, mushollah ini termasuk dalam kelurahan Bulak yang memiliki satu Ketua Takmir yaitu Bapak Fais. Dalam penelitian ini disamping lingkungan yang bersebelahan, para remaja yang berbaur menjadi satu juga sebagai alasan dari

\footnotetext{
${ }^{33}$ Ahmad Amin, Etika (Ilmu Akhlak), Jakarta : Bulan Bintang, 1995, Cet. 8, 63-65

${ }^{34}$ Sugiyono, Metode Penelitian Kuantitatif, Kualitatif, dan R \& D, Bandung : Alfabeta, Cet-11, 2010, h. 246
}

243 | MODELING, Volume 6, Nomor 2, September 2019 
pengambilan peneliti. Warga disini masih kental dengan kegiatan keagamaan baik berupa pengajian, slametan, ataupun lainnya.

Berdasarkan hasil wawancara peneliti dengan ketua dan tokoh masyarakat setempat bahwa pengajian remaja Mushollah Al-Fath didirikan sejak bulan ramadhan tahun 1999, bermula dari sebuah organisasi kecil yang diberi nama IRMA (Ikatan Remaja Mushollah Al-Fath) yang berdiri pada tahun 1998.

Dengan seiringnya waktu dan kemauan para remaja serta dukungan masyarakat setempat, akhirnya pengajian ini sebagai aktifitas rutin mingguan, bulanan, bahkan tahunan bagi para remaja di sini, selain itu mereka menganggap bahwa dengan adanya pengajian dapat menjalin silaturrahim dengan sesama remaja sekitar, dan saling bertukar pendapat atau gagasan tentang apa yang belum mereka ketahui, terlebih dalam pengetahuan agama.

Tak hanya itu saja, mereka lebih banyak berdiskusi dan mengemukakan pendapat masing-masing sebagai adat kebiasaan remaja guna mempersiapkan kemajuan di masa yang akan datang.

Dahulu pengajian ini hanya dihadiri segelintir orang saja, tak lebih dari 10 remaja. Namun, dengan berjalannya waktu Alhamdulillah setiap tahun semakin bertambah, hingga saat ini terdapat 50 remaja. Bagi mereka pengajian merupakan sebuah wadah untuk menambah ilmu terutama ilmu agama, dan sebagai wadah untuk mengadakan beberapa kegiatan positif lainnya.

Tujuan dari pengajian ini adalah untuk mengupayakan tercapainya cita-cita generasi muda ke arah perbaikan di bidang pendidikan dan kesejahteraan, serta terbinanya kehidupan beragama di kalangan mereka. Selain itu juga untuk mempererat Ukhuwah Islamiyah antara para generasi muda, mendidik mereka agar menjadi manusia yang berakhlak mulia, bertaqwa, menghayati dan mengajarkan ajaran Islam, serta terhindar dari lingkungan yang negatif, sehingga pada akhirnya mereka memiliki kepribadian yang bertanggungjawab terhadap pendidikan, bangsa, keluarga, dan masyarakat.

\section{Kondisi Guru/Ustadz dan Anggota}

Saat ini kepengurusan di bawah pimpinan saudara Aminun, Ustadz Samsul Ma'arif sebagai pembina pengajian remaja ini, dan Ustadz M. Sholihin Qodir sebagai tokoh masyarakat setempat. Untuk keanggotaan pengajian ini sekarang berjumlah 50 orang dengan beragam usia remaja, mulai umur 13 sampai dengan umur 23.

Sementara untuk pengajian rutinan tiap minggu, barokah kirim do'a dan AlFatihah dipimpin langsung oleh tokoh masyarakat setempat, dan penyampaian materi akhlak, diisi secara bergantian oleh Ustadz Samsul Ma'arif dan Ustadz Sholihin Qodir.

Untuk pengajian setiap bulan diisi oleh beberapa ustadz dari luar, namun jika berhalangan, diisi dengan kegiatan banjari atau azhari yang dipimpin oleh ketua kepengurusan yaitu saudara Aminun. 


\section{Latar belakang faktor berdirinya pengajian remaja Mushollah Al-Fath}

Sebagai dasar latar belakang dari faktor berdirinya pengajian remaja ini adalah kekhawatiran para sesepuh masyarakat terhadap akhlak generasi muda (remaja), yang pada saat itu kurang mendapat perhatian dari orang tua dan lingkungan sekitar, kurangnya rasa tanggungjawab dalam memperhatikan tugas mereka sebagai seorang muslim, dan kondisi zaman yang terus berkembang sehingga dapat menjerumuskan mereka dalam pergaulan yang kurang benar, dan nantinya menyebabkan keterbelakangan moral serta keterpurukan akhlak.

Ustadz Sholihin mengatakan :

Menurut yang saya ketahui bahwa dulunya para remaja disini sangat enggan untuk diajak pengajian, kebiasaan mereka dalam permainan adu burung dara sangat sulit sekali dihilangkan, hingga akhirnya ada tiga sesepuh sebelum saya yang berhasil merangkup dan mengajak beberapa dari mereka yang diantaranya adalah kepala kelompoknya. Menurut yang saya ketahui awalnya ada teman mereka yang meninggal muda dan tidak sakit, kemudian mereka mulai bertanya-tanya tentang kematian dan seputar agama kepada sesepuh masyarakat pada saat itu, yang kebetulan sesepuhnya adalah kakak saya sendiri, sebagai sesepuh tentu kakak saya menjawab pertanyaan dengan bahasa yang bisa diterima oleh mereka, dan dari sinilah kakak saya sedikit demi sedikit mencoba untuk mengajak mereka untuk ikut pengajian agar mereka bisa mendapatkan pengetahuan yang lebih luas tentang agama, walaupun pada akhirnya tidak semua dari mereka yang ikut. ${ }^{35}$

Karenanya, pengajian remaja Mushollah Al-Fath sebagai bentuk wadah bagi mereka untuk benteng diri, bimbingan, dan arahan agar lebih berakhlak dan siap menghadapi segala tantangan yang akan terjadi di era seperti sekarang ini.

\section{Materi Ajar dan Metode yang digunakan}

Pelajaran yang diajarkan di pengajian remaja Mushollah AL-Fath ini sebagai berikut: Pertama, materi akhlak, sebagai bentuk pembelajaran remaja tentang pertumbuhan dan perkembangan dalam beradab, dan bergaul terutama cara bertingkah, bertutur kata, berbusana, sopan santun dan menghormati orang lain yang baik menurut pendidikan agama. Dengan demikian diharapkan terdapat perubahan sikap dari remaja menuju kedewasaan dalam pola pikir dan bertingkah laku. Kedua, materi ibadah yang meliputi tata cara beribadah menurut ajaran Islam sehingga mereka dapat menerapkan di masyarakat. Dan ketiga, materi tentang cara berorganisasi secara Islami di lingkungan mereka.

Untuk metode yang digunakan dalam pengajian ini ialah metode ceramah, tanya jawab, dan diskusi. Sementara dalam penyampaian materi, khususnya materi akhlak, terdapat beberapa proses dan cara yang dapat dilakukan dalam pembentukan akhlak generasi muda, antara lain melalui pembiasaan, pergaulan, keteladanan, dan pemberian beberapa latihan.

35 Hasil wawancara dengan Ustadz Sholihin Qodir Tanggal 15 September 2017, Jam 18.40 


\section{Faktor Pendukung dan Penghambat}

Faktor pendukung pelaksanaan pengajian diantaranya dorongan para orang tua agar anaknya ikut dalam pengajian ini, guru atau ustadz yang profesional dan berkompeten dalam bidangnya serta memahami apa yang dibutuhkan para remaja, partisipasi para remaja senior yang selalu mengajak teman sebayanya untuk mengikuti pengajian ini.

Sedangkan faktor penghambatnya adalah keadaan lingkungan, ekonomi remaja yang terbatas, dan kurang sadarnya dalam waktu.

\section{Sarana Prasarana dan Kegiatan-Kegiatan}

Pengajian ini dilaksanakan di Musholla Al-Fath yang berada di lingkungan Lebak Jaya Utara 4 Rawasan, dengan sarana dan prasarana yang sederhana, seperti recorder, meja lipat, piring, gelas, dan karpet gulung.

Adapun kegiatan yang dilaksanakan adalah kegiatan rutin mingguan setiap kamis malam jum'at, kegiatan bulanan setiap jum'at kliwon, kegiatan keagamaan setiap hari besar Islam, seperti pembacaan diba' pada bulan maulid, dzikir dan istighosah pada isro' mi'roj dan lain sebagainya. Kegiatan bakti sosial seperti santunan anak yatim pada bulan muharrom, bagi-bagi ta'jil pada bulan ramadhan, dan lainnya. Kegiatan tahunan yaitu ziarah wali 5 yang biasanya diadakan pada akhir tahun.

Untuk acara pengajian yang berlangsung pada kamis malam jum'at, saudara Aminun sebagai ketua pengajian menjelaskan sebagai berikut :36

Pengajian Kamis malam jum'at berlangsung dari pukul 19.00 - 20.30 WIB para jamaah mulai membuka kitab Al-Qur'an atau kitab Ta'limul Muta'allim. Adapun agenda pengajiannya yaitu :

1. Pembacaan Diba'iyah singkat (Sholawat Nabi Muhammad SAW)

2. Pembacaan barokah Al Fatihah

3. Pembacaan Tahlil dan Istighosah, atau pembacaan salah satu surat pilihan

a. Surat Yasin

b. Surat Al Waqiah

c. Surat Al Mulk

4. Sorogan kitab Ta'limul Muta'allim

5. Do'a (Penutup)

\section{Kontribusi Pembentukan Akhlak}

Untuk kontribusi remaja dalam pembentukan akhlak adalah semenjak diadakan pengajian ini, musholla yang dulu saat sholat jamaah hanya diisi para orang tua saja, kini diisi para remaja. Namun, yang lebih tampak kontribusinya adalah rasa saling mengingatkan dalam diri mereka sehingga mengajak praremaja untuk mengaji, dan sebagai bentuk latihan untuk menjadi pribadi yang bertanggungjawab, diantara mereka menjadi tutor atas temannya dalam

\footnotetext{
${ }^{36}$ Hasil Wawancara dengan ketua pengajian saudara Aminun pada tanggal 17 September 2017, Jam 19.50
} 
mengaji Al-Qur'an. Sedangkan untuk acara bulanan mereka juga tak segan untuk meminta pendapat dari tokoh masyarakat setempat.

Beberapa masyarakat juga mengatakan bahwa para remaja di sini lebih memiliki unggah-ungguh terhadap orang yang lebih tua, walaupun tidak semua. Salah seorang masyarakat yang bernama Pak Fauzi mengatakan :

Para remaja disini sangat dikenal dengan jalinan persaudaraan yang sangat kuat, memang saya akui kebiasaan jelek yang lama masih ada, tapi biarpun demikian berbeda dengan dulu, jika dulu mereka tak tergerak hatinya sama sekali untuk ikut dalam pengajian, sekarang mereka sudah tergerak, sehingga bisa dikatakan biarpun berdosa tapi tetap berusaha untuk mensucikannya. ${ }^{37}$

Hal diatas dapat dibuktikan dengan hasil angket yang tersebar bahwa 90\% menyatakan bahwa mereka mengakui pengajian menjadikan diri mereka lebih baik.

\section{Kesimpulan}

Berdasarkan uraian di atas dapat disimpulkan bahwa pengajian remaja sebuah wadah bagi mereka untuk menjalin ukhuwah Islamiyah dan belajar agama, sebagai bekal untuk masa depan mereka sehingga mampu membentuk kepribadian yang sholih ataupun sholihah.

Mushollah Al-Fath ini sebagai gambaran bahwa pengajian remaja memiliki kontribusi yang sangat besar dalam pembentukan akhlak generasi muda di kemudian hari, wilayah ini mempersiapkan generasinya dengan hal positif sehingga menjadi sebuah kebiasaan bagi para remaja menghadiri sebuah pengajian, sebagai latihan penanaman rasa tanggungjawab dengan menjadi tutor, tanpa menghilangkan masa remaja mereka, karena masyarakat tetap memberi kebebasan bagi mereka untuk bermain dan bergaul seperti layaknya remaja lainnya.

\section{Daftar Pustaka}

Ahira, Anne, Terminologi Kosa Kata, Jakarta : Aksara, 2012

Ali, Mohammad Daud, Pendidikan Agama Islam, Jakarta : Rajawalin Press, 2008

Amin, Ahmad, Etika (Ilmu Akhlak), Jakarta : Bulan Bintang, Cet. 8, 1995

Cahyaningsih, Dwi Sulistyo, Pertumbuhan Perkembangan Anak dan Remaja, Jakarta : Trans Info Media, 2011

Chirzin, Habib, Pesantren dan Pembaharuan, Jakarta : LP3ES, Cet. 3, 1983

Daradjat, Zakiah, Ilmu Gama, Jakarta : Bulan Bintang, Cet. Ke-14, 1970

Depag RI, Al Qur'an dan Terjemahannya, Jakarta : Proyek Pengadaan Kitab Suci AlQur'an , 1983/1984

Dewan Redaksi Ensiklopedia Islam, Ensiklopedia Islam, Jakarta : Ichtiar Baru Van Hoeve, Cet. Ke-4, Jilid 3, 1997

\footnotetext{
${ }^{37}$ Hasil Wawancara dengan salah seseorang masyarakat yang bernama Pak Fauzi pada tanggal 27 September 2017, Jam 18.30
} 
Dirdjosanjoto, Pradjarta, Memelihara Umat (Kiai Pesantren-Kiai Langgar di Jawa), Yogyakarta : LKIS, 1999

Djoenaesih, Soerjono, Istilah Komunikasi, Yogyakarta : Liberty, 1997

Djony, Gunadi, Istilah Komunikasi, Jakarta : Grafindo Persada, 2013

Drajat, Zakiah, Remaja Harapan dan Tantangan, cet. Ke-2, Jakarta : Ruhama, 1995

Ghazali, Bahri, Pesantren Berwawasan Lingkungan, Jakarta : Prasasti, 2003

Hasbullah, Kapita Selekta Pendidikan Islam di Indonesia, Jakarta : Raja Grfindo Persada, 1999

King, Laura, The Science of Psicology : An Appreciative View, Jakarta : Salemba Humanika, 2012

Mustafa, Akhlak Tasawuf, Bandung : Pustaka Setia, Cet. 3, 2005

Nata, Abuddin, Akhlak Tasawuf, Jakarta : Rajawali Pers, 2009

Nurwahid, Hidayat, Pengantar Sejarah Dakwah, Jakarta : Kencana, 2012

Ramayulis, Ilmu Pendidikan Islam, Jakarta : Kalam Mulia, Cet. 1, 1994

Saebani, Beni Ahmad, Abdul Hamid, Ilmu Akhlak, Bandung : Pustaka Setia, Cet. 2, 2012

Salim, Abdullah, Akhlak Islam Membina Rumah Tangga dan Masyarakat, Jakarta : Seri

Remaja, 1986

Sugiyono, Metode Penelitian Kuantitatif, Kualitatif, dan $R \& D$, Bandung : Alfabeta, Cet11,2010

Suparta, Munzier, Metode Dakwah, Jakarta : Kencana, 2009

Suraji, Imam, Etika Dalam Perspektif Al- Qur'an Dan Hadits, Jakarta : Pustaka Al-Husna Baru, 2006

Suryabrata, Sumadi, Psikologi Pendidikan, Jakarta : Rajagrafindo Persada, 2008

Tim Redaksi Kamus Besar Bahasa Indonesia, Kamus Besar Bahasa Indonesia Edisi Ketiga, Jakarta : Balai Pustaka, ed. 3, Cet. 2, 2005

Yusuf, Psikologi Perkembangan Anak dan Remaja, Bandung : Remaja Rosdakarya, Cet. 10, 2010

Yusuf, Syamsul, Psikologi Perkembangan Anak dan Remaja, Bandung : Remaja Rosdakarya, 2004

Zulkifli, Psikologi Perkembangan, Bandung : Remaja Rosdakarya, 2002 